\title{
A AMÉRICA ESPANHOLA EM 1830 E COROAÇÃO DE BOLIVAR
}

\author{
Earle D. Macarthy Moreira
}

Com esse título e constituindo matéria de primeira página, o conceituado "Jornal do Comércio" do Rio de Janeiro, nas edições de 14,16 e 17 de abril de 1830, dava ampla divulgação de um "extracto" ou resumo "de huma obra transcendente", de cujo autor não registra o nome mas abona a idoneidade.

A finalidade da publicação era fundamentalmente didático-política. Visava levar à consideração das classes dirigentes da nação, num momento em que a crise interna, destinada a culminar com os sucessos de 7 de abril do ano seguinte, se agravava, uma mensagem de ponderação e um alerta. O quadro de instabilidade política da América Espanhola, com suas sangrentas e constantes revoluções, com o respectivo cortejo de perigos para a ordem social e econômica, aparece bem destacado pelo autor dos artigos que, na esteira de Tácito, encaminha o leitor a meditar sobre a conturbada situação do Brasil e sobre os rumos de seu futuro.

O mais representativo órgão das classes produtoras do Império, conquanto não se deixasse envolver nas virulentas pasquinadas típicas da época, esforçando-se mesmo por manter um cunho de sobranceria e respeitabilidade em seus pronunciamentos, nem por isso deixou de assumir as suas próprias posições doutrinárias, as quais, como se pode perceber da matéria em apreço, eram as seguintes:

1) a missão da imprensa não é fomentar ódios alheios e muito menos desafogar paixões pessoais;

2) a calúnia é arma baixa e desprezível, indigna do jornalismo responsável;

3) o respeito às opiniões alheias é postulado fundamental do jogo político, cabendo ao analista o exame frio dos partidos sempre tendo em vista o superior interesse nacional;

4) as revoluções são, de per si, indesejáveis, eis que alteram a evolução natural dos povos, nas mais das vezes, para descaminhos tormentosos, desordens e catástrofes;

5) a estabilidade institucional faz a felicidade dos povos;

6) as revoluções afetam a unidade e a segurança nacional;

7) a anarquia depois de desencadeada é de difícil controle, levando de roldão no seu tropel o Estado, a Igreja, a Propriedade e deixando em seu lugar o sangue, a morte, o crime e a tirania;

8) não é possível deixar de ressaltar que os países da América Espanhola, toda ela mergulhada na revolução e na anarquia, têm em comum o sistema republicano; 
9) se a prática comprova a teoria; o sistema republicano deixa muito a desejar; é até perigoso, se levada em conta a experiência da América Espanhola, onde as eleições são uma fraude, os assassinatos constituem a regra da sucessão política, o caudilhismo sufoca o progresso e restaura o feudalismo, nem a honra das mulheres sendo respeitada pela ralé desenfreada;

10) os próprios hispano-americanos aspiram por governos fortes que aliem à manutenção da ordem o respeito aos direitos dos cidadãos;

11) a monarquia moderada ou constitucional é comprovadamente compatível com os ideais da independência americana e o melhor sistema de governo.

Em seu último artigo, o autor do resumo - resumo que em meu entender serve à intenção doutrinária do jornal - desvia, com forte guinada, o curso de suas considerações, atribuindo ao sistema colonial espanhol e seus vícios grande parcela de culpa pelo estado caótico de seus ex-domínios; com tal argumento pretende demonstrar não ser solução razoável um retorno ao status quo anterior. Impunha-se a ressalva. Não fossem os vizinhos - platinos, principalmente, com os quais mal havíamos chegado a um acerto, concluída que fora em 1828 a Questão Cisplatina - supor qualquer espécie de concordância com a renitente política imperial de Fernando VII, espectro ainda presente e algo assustador que vinha de corporificar-se, recentemente, na malfadada expedição do general Barradas ao México. (Vide O Amigo do Homem, e da Pátria, Rio Grande, números de 11/8, 27/11 e 29/12/1829. Idem, Jornal do Commercio, Rio de Janeiro, números de 6/4/1829; 5, 7, 15 e $25 / 1 / 1830 ; 6 / 2 / 1830 ; 18$ e $22 / 4 / 1830$.)

Nessa mesma oportunidade o articulista, um pouco por convicção ideológica e muito por manha profissional, procura uma abertura. Não fossem os acontecimentos derivando para rumos outros do pretendido, à força de ventos contrários e incontroláveis. . Deveria haver sempre uma possibilidade de composição para o futuro, qualquer que fosse o regime a ser instaurado. Daí os "poréns":

Huma força invencivel attrahe á mudança; as causas deste phenomeno não se explicão sempre por meio das regras comuns, nem são effeito do acaso nem dos caprichos dos povos. A Providencia encerra em si mesma acontecimentos impenetraveis, etc.

Esta última vem aí invocada como poder mais alto. Por outras palavras, "o homem põe e Deus dispõe”. E quem sabe lá se uma revolução, à moda dos Estados Unidos ou da França, não seria como o famigerado purgante de óleo de rícino, ruim de engolir mas de benéficos efeitos?

A conclusão, doutoral, deve por força inscrever-se na árvore genealógica das máximas acacianas:

Conciliar os interesses novos e velhos, dominar os partidos internos e externos seria a politica a mais acertada a adoptar e a seguir.

Al fin y al cabo, o período regencial que se avizinhava a passos largos, com seu rol de badernas e arruaças, constantes crises políticas e revoluções de todos os matizes, pondo em risco a cada momento não só a economia como a própria unidade nacional, não 
deix ou de convalidar as justas preocupações do jornalista. Por outro lado, o mesmo não se viu fraudado nas conclusões que tirou da história, de que "as revoluções são para os estados melhoramentos mais ou menos dolorosos, porém que deixão sempre como resultado hum augmento do poder". O Ato Adicional de 12 de agosto de 1834 não só inovou a Constituição outorgada como despiu-a do pecado original, dando-lhe o referendo legislativo em alta e boa forma. 0 supremo instrumento jurídico da nação foi, ainda, devidamente afinado às realidades do país pela Lei Interpretativa de 12 de maio de 1840. A antecipação da maioridade de D. Pedro II, por sua vez, e o conseqüente fortalecimento do sistema monárquico e parlamentar que destacou o Brasil no conjunto das nações latino-americanas, até quase o final do século passado, constituir-se-ão em resposta positiva aos nove anos de agitação regencial.

Departamento de História

Pontifícia Universidade Católica

Porto Alegre, Brasil 